\title{
IMPULSANDO LA INVESTIGACIÓN
}

Revista Alternativas viene presentando en sus últimas ediciones los cambios estructurales necesarios con las normas establecidas para cumplir con el compromiso de elevar su nivel de producción científica. Como toda publicación, más aún si es la revista científica de la Universidad Católica de Santiago de Guayaquil, está realizando cambios de fondo y forma que esperamos tenga la acogida de nuestros lectores.

Esta circulación cumplió ya 15 años ininterrumpidos a la comunidad. En este lapso hemos trasmitido la imagen de la Academia Católica con la publicación de la producción intelectual de sus profesores e investigadores. Contamos además con la valiosa colaboración de valiosos profesionales de Institutos de Educación Superior, que integran la oferta educativa superior, lo que permite añadir su proyección exógena, necesaria para cumplir con las exigencias de evaluación requeridas por los Organismos responsables de la indexación de estos medios de difusión académica-científica.
Es grato presentar trabajos de gran valía en diversas ramas del saber científico, que son producto del gran impulso que está dando a la investigación como parte fundamental de las políticas de desarrollo trazadas por nuestras autoridades universitarias y que responden a una imperiosa necesidad de nuestro país que debe abrirse a nuevos campos del saber humano en un mundo altamente competitivo y diversificado.

Los resultados no pueden medirse en un corto plazo, pero sí se puede avizorar un prometedor futuro si se persiste en esta línea. Los lectores de "Alternativas" son parte de ese proceso, pues los artículos divulgan aspectos innovadores de la ciencia, inducen a la reflexión y contribuyen al debate intelectual, tan necesario en una sociedad.

El equipo editorial que labora en esta Revista continuará esforzándose por ser el fiel vocero a su compromiso y pensamiento de la Universidad Católica de Santiago de Guayaquil.

Econ. Mauro Toscanini Segale, MBA. MSc. 